\section{Management Of A Patient With A Rare Variant Of Autoimmune Polyglandular Syndrome of The Second Type}

\author{
Negmatova Gulzoda Shuhratovna, \\ Samarkand State Medical Institute, Samarkand, Republic \\ Of Uzbekistan
}

G Open ACCESS

The American Journal of
Medical Sciences And
Pharmaceutical
Research
JULY 2020
Page No.: $24-30$
Volume-II Issue-VII
PUBLISHED: 30 JULY 2020
www.usajournalshub.com/inde
x.php/TAJMSPR
Copyright: Original content
from this work may be used
under the terms of the
Creative Commons Attribution
4.0 licence.

\title{
Abstract
}

The article considers a clinical case of a young patient with autoimmune polyglandular syndrome type 2, represented by type 1 diabetes mellitus, thyroid dysfunction and primary adrenal cortex insufficiency.

Keywords: autoimmune polyglandular syndrome type 2, type 1 diabetes mellitus, chronic autoimmune thyroiditis, primary chronic adrenal insufficiency, vitiligo.

\section{Introduction}

Polyglandular insufficiency syndromes are characterized by a sequential or simultaneous decrease in the function of several endocrine glands, which are based on a common cause -an autoimmune process in the corresponding organs and tissues.

Classification depends on the combination of insufficiency of individual glands, which are combined in 1 of 4 types. The underlying autoimmune response is mediated by autoantibodies to endocrine tissues, leading to inflammation, lymphocytic infiltration, and partial or complete destruction of glandular tissue. Several endocrine glands are involved in the process, although the clinical manifestations of this pathology do not always occur simultaneously. Immune system dysfunction sometimes causes autoimmune reactions in non-endocrine tissues as well. The diagnosis requires determining the levels of hormones and autoantibodies to the affected endocrine glands. 
Clinical polymorphism, a long monosymptomatic course, and a long latent period between the onset of symptoms of the syndrome require modern immunological methods of diagnosis and monitoring of the residual function of the target organ in order to timely start therapy and prevent crisis conditions. Treatment is reduced to mixing the missing hormones, and sometimes to the use of immunosuppressant's.

Polyglandular syndrome includes a wide range of autoimmune disorders. George $\mathrm{J}$. Kahaly identifies two main types of autoimmune polyglandular syndrome (AIPS): juvenile (type 1) and adult AIPS (type 2). In the nature of AIPS, the leading role is played by: infiltration by lymphocytes of the affected gland, circulation of organ-specific antibodies in serum, immune defects in cells, and Association with (HLA) DR/DQ genes [11]. The most common is AIPS 2. Its main components are primary adrenal insufficiency (Addison's disease), autoimmune diseases of the thyroid gland and/or type 1 diabetes mellitus (type 1 diabetes). Autoimmune thyroid disease represented by chronic autoimmune thyroiditis Hashimoto's or Graves' disease. However, there may be other components of type 2 AIPS: primary hypogonadism, myasthenia, celiac disease, pernicious anemia, allopecia, vitiligo, serositis. Type 2 AIPS is a polygenic disease, based on a genetic predisposition to autoimmune tissue damage as a result of the presence of specific HLA genes (DR3, DR4, B8, DQA1, etc.). Classic type 2 AIPS is characterized by the presence of primary CNS and autoimmune thyroid damage-graves ' disease or hypothyroidism in the outcome of autoimmune thyroiditis (AIT). This combination is commonly called Schmidt's syndrome, a combination of primary HNN with thyroid damage and type 1 diabetes-carpenter's syndrome. Foreign researchers (Betterle) modified this classification by adding types 3 and 4 AIPS, which are identical in their pathogenesis to type 2 AIPS, but are characterized by combinations of autoimmune lesions other than type 2 AIPS.

\section{Autoimmune polyglandular syndromes}
A) type 1
1) chronic Muco-cutaneous candidiasis
2) hypoparathyroidism
3) chronic adrenal insufficiency
A) type 2
1) chronic adrenal insufficiency
2) insulin-dependent diabetes mellitus
3) defeat of the thyroid gland.

Wolf-Parkinson-white syndrome (WPW syndrome) is the most common syndrome of premature ventricular arousal (it is observed in $0.1-0.3 \%$ of the population in the General population), which occurs in the presence of an additional bundle of Kent, most people do not have signs of heart disease. Despite great advances in the study of the disease, the molecular and genetic basis responsible for the syndrome in most patients remains unknown. As of March 2020, only a few genes are known, the violation of which leads to Wolff-Parkinson-White syndrome.

CTLA-4 and PD-1 are expressed (produced) on T-lymphocytes when activated, and are membrane immunoglobulins. PD-1 is a marker of activated T-lymphocytes. Inhibitory 
receptors CTLA-4 and PD-1 (modulators of the immune synapse) play a key role in the regulation of immune responses. They suppress the over-development of the immune response and prevent autoimmune reactions. CTLA-4 and PD- 1 weaken the function of effector (acting, Executive) T-lymphocytes. CD28-a membrane protein expressed on Tlymphocytes, participates in the stimulation of T-lymphocytes. Binding of the Tlymphocyte receptor to the antigen-HKG complex in the absence of a stimulating signal from CD28 leads to the inability of the lymphocyte to provide a normal immune response and lymphocyte tolerance.

T-lymphocytic receptor (TCR), a surface protein complex of T-lymphocytes responsible for recognizing processed antigens associated with molecules of the main histocompatibility complex (HKG, MHC) on the surface of antigen-presenting cells. The interaction of TCR with $\mathrm{gkg}$ molecules and their associated antigen leads to the activation of T-lymphocytes and is a key point in triggering the immune response. In the molecular mechanisms of t-lymphocyte activity suppression, we see that CTLA-4 competitively inhibits CD28, which leads to a decrease in rGKG/TCR and PD-1 production.

However, under the influence of various exogenous and/or endogenous factors, mutations of various genes can occur, a variety of which can serve as a gene deletion, that is, destruction-chromosomal rearrangement with the loss of a section of the chromosome. In experimental deletion in mice with PD-1 deficiency, it was found that this eventually leads to autoimmune dilated cardiomyopathy or autoimmune myocarditis [12]. Currently, there are no descriptions in the scientific literature of cases with damage to the gene that defines the PD-1 protein.

Purpose Of Work: to Show the importance of timely diagnosis and treatment of type 2 AIPS in clinical practice.

Research Methodology: In our clinical practice, we have encountered a rare and atypical variant of the manifestation and course of type 2 AIPS and present to your attention a clinical observation of a young man with type 2 AIPS, represented by type 1 diabetes, impaired thyroid function and primary adrenal cortex insufficiency.

\begin{tabular}{|c|c|c|}
\hline Specifications & 1 type & 2 type \\
\hline $\begin{array}{l}\text { Inheritance } \\
\text { Genetic Association or } \\
\text { relationship } \\
\text { Sexs } \\
\text { Age at the beginning }\end{array}$ & $\begin{array}{l}\text { Autosomal recessive } \\
\text { Related to the external } \\
\text { environment } \\
\text { Equal distribution } \\
\text { Young age }\end{array}$ & $\begin{array}{l}\text { Polygenic } \\
\text { Some HLA's }\end{array}$ \\
\hline $\begin{array}{l}\text { Endocrine disorders } \\
\text { Addison's Disease } \\
\text { Hypoparathyroidism } \\
\text { Autoimmune thyroid } \\
\text { disease } \\
\text { Type } 1 \text { diabetes } \\
\text { Primary hypogonadism } \\
\text { Pituitary }\end{array}$ & $\begin{array}{l}60-72 \% \\
\text { Ordinary (79- } \\
96 \%) \\
\text { Less frequently (about } \\
5 \%) 14 \% \\
\text { of these, } 60 \% \text { are }\end{array}$ & $\begin{array}{l}70 \% \\
\text { Rare } \\
\text { More often (about } \\
70 \%)>50 \% \\
\text { About } 5 \% \\
\text { - }\end{array}$ \\
\hline
\end{tabular}




\begin{tabular}{|c|c|c|}
\hline & women; $14 \%$ are men- & Meets \\
\hline $\begin{array}{l}\text { Dermatological } \\
\text { Chronic } \\
\text { mucoviscidosis } \\
\text { Skin candidiasis } \\
\text { Allopecias } \\
\text { Vitiligo } \\
\text { Dermatitis herpetiformis }\end{array}$ & $\begin{array}{l}\text { Often at the beginning } \\
\text { (about } 100 \%) \\
\text { General (about } 50 \% \text { ) } \\
\text { About } 13 \% \text { - } \\
\text { - }\end{array}$ & $\begin{array}{l}\text { - } \\
\text { Meets } \\
\text { Около 5\% } \\
\text { Meets } \\
\text { Meets } \\
\end{array}$ \\
\hline $\begin{array}{l}\text { Gastro-intestinal } \\
\text { Celiac } \\
\text { Autoimmune hepatitis }\end{array}$ & $\begin{array}{l}\text { No (only steatorrhea) } \\
\text { About } 12 \%\end{array}$ & Present in $2-3 \%-$ \\
\hline $\begin{array}{l}\text { Hematological } \\
\text { Pernicious anemia } \\
\text { Erythrocytic } \\
\text { Hypoplasia } \\
\text { Idiopathic } \\
\text { thrombocytopenic } \\
\text { purpura }\end{array}$ & $\begin{array}{l}\text { About 13\% } \\
\text { Meets } \\
\text { Never meet }\end{array}$ & $\begin{array}{l}\text { As often as in } \\
\text { APS } \\
- \\
\text { Meets }\end{array}$ \\
\hline $\begin{array}{l}\text { Ectodermal } \\
\text { Enamel hypoplasia } \\
\text { Nail dystrophy } \\
\text { Calcification of the } \\
\text { eardrum }\end{array}$ & $\begin{array}{l}+ \\
+ \\
+ \\
+\end{array}$ & $\begin{array}{l}- \\
- \\
-\end{array}$ \\
\hline $\begin{array}{l}\text { Neurological } \\
\text { Myasthenia } \\
\text { Stifman Syndrome } \\
\text { Parkinson } \\
\end{array}$ & $\begin{array}{l}- \\
- \\
-\end{array}$ & $\begin{array}{l}+ \\
+ \\
+\end{array}$ \\
\hline $\begin{array}{l}\text { Other } \\
\text { Asplenia } \\
\text { Keratopathy } \\
\text { Progressive } \\
\text { Myopathy } \\
\text { Deficit IgA } \\
\text { Serozit } \\
\text { Idiopathic heart block }\end{array}$ & $\begin{array}{l}+ \\
+ \\
+ \\
- \\
- \\
- \\
-\end{array}$ & $\begin{array}{l}- \\
- \\
- \\
+ \\
+ \\
+ \\
+\end{array}$ \\
\hline
\end{tabular}

The Results Of The Study And Their Discussion: In 2019, patient X., at the age of 32, turned to the Samarkand endocrinological dispensary with complaints: dry mouth, increased blood glucose, increased skin depigmentation, weakness, loss of apetite, increased $A \backslash D$, tachycardia, infertility.

According to the patient, he has been ill since the age of 17. From 2012 to 2014, he was in Russia for treatment of vitiligo. At the same time, during sports, he suffered a dislocation of the left shoulder, the treatment of which led to the development of allergies to NSAIDs and penicillin. Several times there was anaphylactic shock with swelling of the 
face and larynx. Took the GCS. Since 2016, he has been suffering from type 1 diabetes. In the beginning, I took biguanides $500 \mathrm{mg} /$ day. Currently, it receives analogs of human insulin of prolonged action at a dose of 16 units \day. In 2017, he was treated for palpitations in a cardiology clinic with a diagnosis of WPW syndrome. After the wedding, there were no children for a year. On this occasion, an analysis was conducted and azoospermia was detected.

\section{From anamnesis:}

the Child in the family is the first in a row, was born on time, height $52 \mathrm{~cm}$, body weight $3200 \mathrm{~kg}$, the newborn period proceeded without deviations. Grew and developed well. Started walking at 1 year and 2 months, speech development at 1 year. As a child, he suffered from chicken pox. Vitiligo was detected at the age of 12 . He began to be examined in 2017 due to infertility and successively revealed azoospermia, AIT and type 1 diabetes in 2017, WPW syndrome in 2018, suffered twice anaphylactic shock in 2017. The mother had this pregnancy for the first time, it was difficult, with toxicities of the entire pregnancy period. The mother in the early stages of pregnancy was ill with SARS, flu, took glucose, ascorbic acid. The boy's parents do not suffer from any chronic diseases, have another healthy child, and the marriage is not related. Has no bad habits.

During the inspection, the overall condition is satisfactory. The skin is dark with large areas of depigmentation. The visible mucous membranes are pale and dry. The lymph nodes available for palpation are not enlarged. The thyroid gland is located in a typical place, when palpated, compacted, not enlarged, the surface is uneven and rough, painful. Hemodynamics is stable: blood pressure $130 / 90 \mathrm{~mm} \mathrm{Hg}$..

found:

During the examination in the Samarkand regional endocrinological dispensary

In the biochemical analysis of blood protein-78 $\mathrm{g} / \mathrm{l}$, cholesterol $-3.0 \mathrm{mmol} / \mathrm{l}$, albumin $-38.4 \mathrm{~g} / \mathrm{l}$, urea $-6.1 \mathrm{mmol} / \mathrm{l}$, biluribin $-11.9 \mathrm{mmol} / \mathrm{l}$, glucose $-8.0 \mathrm{mmol} / \mathrm{I}$.

On the glycemic profile in $300-7.9 \mathrm{mmol} \backslash \mathrm{I}$, in $700-8,0 \mathrm{mmol} \backslash \mathrm{I}$, in $1000-11,2$ mmol\I, in 1700-8,4 mmol $\backslash$.

In the General analysis of urine glucose- $1 \%$, protein- $0.033 \mathrm{~g} / \mathrm{l}$, epithelium $1-2$ in $\mathrm{p} / \mathrm{W}$, leukocyte 10-11 in $\mathrm{p} / \mathrm{W}$, salt (+).

In the analysis (profile) of thyroid hormones, TSH - $2.45 \mathrm{ng} / \mathrm{ml}$, T4 free-15.8 pmol / l, antitpo-32 IU / ml.

The patient had an increase in glycemic indices to $11.2 \mathrm{mmol} / \mathrm{l}$ with a gradual decrease during the first day to $8.0 \mathrm{mmol} / \mathrm{l}$.

In instrumental methods of research: ultrasound left-sided pyelonephritis, chronic prostatitis. On ultrasound of the thyroid gland, the organ is compacted, of a heterogeneous structure.

ECG shows sinus tachycardia, WPW syndrome, dystrophic changes in the myocardium, signs of hypertrophy of both ventricles.

On EchoCG, the heart chambers are not dilated, there is no hypertrophy of the walls, moderate systolic LV dysfunction, FV 47\%, heart rate-89 beats per minute, the zone of local fibrosis of the anterior-septum segment of the basal and partially middle LV region, the contractility of this area is reduced, diffuse hypokinesia of the LV. 
The patient had a labile course of DM, in which hypoglycemia was replaced by hyperglycemia.

In the conditions of the department of general endocrinology performed: analog of human insulin prolonged action 16 UNITS in 2200, short-acting insulin 6 UNITS before the main meals, Actovegin $400 \mathrm{mg}+$ sodium chloride solution $0.9 \%-200.0 \mathrm{~V} / \mathrm{V}$ drip. Against the background of therapy, the condition was stabilized, the patient was trained in the DM program, and was discharged under the supervision of a district therapist and endocrinologist. The patient was given the following recommendations for pharmacotherapy: prolonged-acting insulin 16 UNITS in 2200, converted to XE for the main meals.

The patient was diagnosed with the following: main-autoimmune polyglandular syndrome type 2: type 1 diabetes, AIT, vitiligo common form. Complications - diabetic nephropathy with proteinuria, CKD-C 2.

The patient was diagnosed with the following: main-autoimmune polyglandular syndrome type 2: type 1 diabetes, AIT, vitiligo common form. Complications - diabetic nephropathy with proteinuria, CKD-C 2.

Concomitant: WPW, heart rhythm disorders of the type of transient paroxysmal tachycardia, myocardiodystrophy.

\section{Conclusion}

On the example of one patient, we concluded that timely diagnosis of AIPC components can prevent the development of severe complications of the components of the syndrome, alleviate the suffering of patients and prevent the deterioration of their quality of life.

Patients with type 2 AIPS should be trained and warned about the symptoms of diseases of which they have a high risk, since during the patient's life, when new components of the syndrome are added, one type of adult AIPS may be reclassified to another [10]. We recommend including the category of people whose work is associated with increased attention, especially in the evening and at night, in the risk factors for developing autoimmune diseases and expanding monitoring at medical examinations to include hormonal blood tests.

\section{Referenses:}

1. Betterle C., Zanchetta R. Update on autoimmune polyendocrine syndromes (APS). Clinical Immunology and Allergology. Acta Bio Medica 2003; 74: 1: 9-33.

2. Kahaly G.J. Polyglandular autoimmune syndromes. Eur J Endocrinol 2009; 161: 1: 1120. doi: 10.1530/eje-09-0044.

3. Endocrinology. National leadership. Edited By I. I. Dedov, G. A. Melnichenko. M: GEOTAR-Media, 2008.

4. Yu. I. Klyuchagina1, Z. A. Sokolova2, M. A. Baryshnikov2. The role of the PD-1 receptor and its PDL1 and PDL2 ligands in tumor immunotherapy. Oncopediatrics. 2017, 4 (1) 4955 pages.

5. L. Tsarev, A.V. Melerzanov, Review of approaches to immunotherapy in Oncology. Journal of Research and practice in medicine 2017, vol. 4, no. 3, pp. 51-65 REVIEW DOI: 
10.17709/2409-2231-2017-4-3-5.

6. Chen Q.Y., Kukreya A., Maclaren N.K. The autoimmune polyglandular syndromes. In: Endocrinology. 4th Ed. Eds. L.J. De Groot, J.L. Jameson. Philadelphia: W.B. SaundersCompany 2001; 41: 587-599.

7. Betterle C., Lazzarotto F., Presotto F. Autoimmune polyglandular syndrome Type 2: the tip of an iceberg? ClinExperimentImmunol 2004; 137: 2: 225-233. doi: 10.1111/j.13652249.2004.02561.x.

8. Betterle C., Dal Pra C., Mantero F., Zanchetta R. Autoimmune Adrenal Insufficiency and Autoimmune Polyendocrine Syndromes: Autoantibodies, Autoantigens, and Their Applicability in Diagnosis and Disease Prediction. EndocrinRev 2002; 23: 3: 327-364. doi: 10.1210/edrv.23.3.0466.

9. Betterle C., Volpato M., Greggio A.N., Presotto F. Type 2 polyglandular autoimmune disease (Schmidt's syndrome). J PediatrEndocrinolMetabol 1996; 9: 1: 113-123.

10. Falorni A., Laureti S., Santeusanio F. Autoantibodies in autoimmune polyendocrine syndrome type II. EndocrinolMetabolClinNorthAm 2002; 31: 2: 369-389.

11. Förster G., Krummenauer F., Kühn I., Beyer J., Kahaly G. Das polyglanduläreAutoimmunsyndromTyp II: Epidemiologie und Manifestationsformen. DMW DeutscheMedizinischeWochenschrift 2008; 124: 49: 1476-1481. doi: 10.1055/s-20081035684,.

12. Papadopoulos K.I., Hallengren B. Polyglandular autoimmune syndrome type II in patients with idiopathic Addison's disease. ActaEndocrinol (Copenhagen) 1990; 122: 4: 472-478.

13. Majeroni B., Patel P. Autoimmune Polyglandular Syndrome, Type II. AmFamPhysic 2007; 75: 5: 667-670.

14. Eisenbarth G.S., Gottlieb P.A. Autoimmune Polyendocrine Syndromes. NewEngl J Med 2004; 350: 20: 2068-2079.

15. Proceedings of the European Congress of Endocrinology, may 2019. 